\title{
27. PALEONTOLOGICAL EVIDENCE FOR THE TRIASSIC AGE OF ROCKS DREDGED FROM THE NORTHERN EXMOUTH PLATEAU (TETHYAN FORAMINIFERS, ECHINODERMS, AND OSTRACODES) ${ }^{1}$
}

\author{
Edith Kristan-Tollmann ${ }^{2}$ and Franz Gramann ${ }^{3}$
}

\begin{abstract}
A very Late Triassic age can be proven by the microfaunal investigation of samples dredged from the northern Exmouth Plateau close to Ocean Drilling Program Site 764. The samples were previously regarded as Lower Jurassic sediments. The microfossils of known stratigraphic ranges show predominant Tethyan affinities.

In samples dredged during Sonne cruise 8 (1979) from the northern slope of the Wombat Plateau, an Early Jurassic age is excluded by the presence of Frondicularia rhaetica, Berthelinella rhaetica, Fissobractites subsymmetrica, Ophioflabellum cristatum, Ophiacantha ? binitorulosa, Mostlerella n. sp., and Hasibuana asiatica. As a whole, a Rhaetian age is indicated. This age is also suggested by the foraminifers Coronipora austriaca and Variostoma sp., from determinations in limestone thin sections.

Samples from Rig Seismic cruise 56 (1986), also from the northern slope of the Wombat Plateau, contain an assemblage of foraminifers known from the Triassic and observed in thin sections of carbonate rocks. They include Trocholina crassa, Trocholina laevis, Variostoma sp., and Variostoma coniforme. In combination with the lithofacies, the assemblage is characteristic for the Rhaetian Dachsteinkalk facies of the Northern Calcareous Alps of Austria.

Thin sections from rocks dredged from Cygnet Canyon are rich in Glomospirella friedli and suggest a Norian to Rhaetian age. A thin section from the nearby Emu Escarpment contains sections of the Anomuran coprolite Octotriangulella septemtriangula Kristan-Tollmann, which is also present in upper Anisian rocks of Papua New Guinea.

The similarity of these characteristic associations of "Alpine" microfaunas and facies types to those of many other sites in the western and easternmost Tethys (Papua New Guinea and Timor) demonstrates a formerly unexpected close similarity of the faunal community throughout the whole Tethys realm.
\end{abstract}

\section{INTRODUCTION}

Dredged rocks from the steep margins of the northern Exmouth Plateau (Swan Canyon, Cygnet Canyon/Emu Escarpment, and Wombat Plateau) were helpful in dating seismic reflectors to obtain a better knowledge of the Triassic to Holocene history of this continental margin (von Stackelberg et al., 1980; Exon et al., 1982; von Rad and Exon, 1983; Exon and Williamson, 1988). The location of the analyzed dredge samples is shown in Figures 1 through 4 (von Rad et al., 1990). Further details on the location, water depth, and lithology of the dredge samples are given in Table 1.

The dredge samples from the stations S08-61KD and S08-62KD were taken in 1979 during cruise 8 of the Sonne at the Wombat Plateau, a small subplateau of the Exmouth Plateau off northwest Australia (Figs. 1, 3, and 4). The Sonne samples had previously been regarded as Early Jurassic (Liassic) in age. The foraminifers had been determined to be Early Jurassic (Sinemurian) by Quilty (1981) and Zobel (in von Stackelberg et al., 1980). Sites 761 and 764 were drilled during Leg 122 of the Ocean Drilling Program (ODP) in the vicinity of the dredge stations (Figs. 3 and 4). The drilled sequence comprises Neogene to Cretaceous sediments, which are underlain by Rhaetian carbonates with Triasina hantkeni, Aulotortus sinuosus, and Glomospirella friedli (Haq, von Rad, O'Connell, et al., 1990).

1 von Rad, U., Haq, B. U., et al., 1992. Proc. ODP, Sci. Results, 122: College Station, TX (Ocean Drilling Program).

2 Scheibenbergstr. 53/6, A-1180 Wien, Austria.

3 Niedersächsisches Landesamt für Bodenforschung (NLfB), Postfach 51 01 53, D 3000 Hannover 51, Federal Republic of Germany.
According to our experience, these foraminifers are typical of shallow-marine platform carbonates deposited in a lagoonal environment. Comparable rock types from the Northern Calcareous Alps with the same assemblage of foraminifers are the bedded Dachsteinkalk and the Hauptdolomit. The carbonate sediments at Sites 761 and 764 can therefore be considered of Norian to Rhaetian age.

These indications of latest Triassic age close to the location of dredge sample S08-61KD caused shipboard foraminiferal paleontologist A. Wonders (in Haq, von Rad, O'Connell, et al., 1990) to doubt the assignment of the dredge samples to the Liassic. He suggested that the samples be restudied and carefully compared with the results from Site 764 (see Haq, von Rad, O'Connell, et al., 1990, pp. 368-369).

In this paper, we followed this suggestion to restudy the biostratigraphy of the dredge samples in more detail. We started with small quantities of the old residues of the S08$61 \mathrm{KD}$ samples, originally studied by Quilty (1981), together with a sample from S08-61KD/2 (Me 9151) studied by B. Zobel and F. Gramann in 1980. These samples proved to contain ostracode genera hitherto known only from the Triassic, together with the foraminifers described by Quilty (1981) as a Sinemurian assemblage. With extension of the ranges of the foraminifers into the Late Triassic based on recent study, a Late Triassic age for the samples from the S08-61KD dredge haul had become a distinct possibility. Based on the species, which were determined in the remaining samples and thin sections, the sediments range into the latest Triassic (Rhaetian or Rhaetian to Norian). The grouping of the material into three units stems from slight differences in lithology, which will be treated in more detail in the following text. We considered not only the foraminifers and ostracodes, but also the echinoderm remains. 


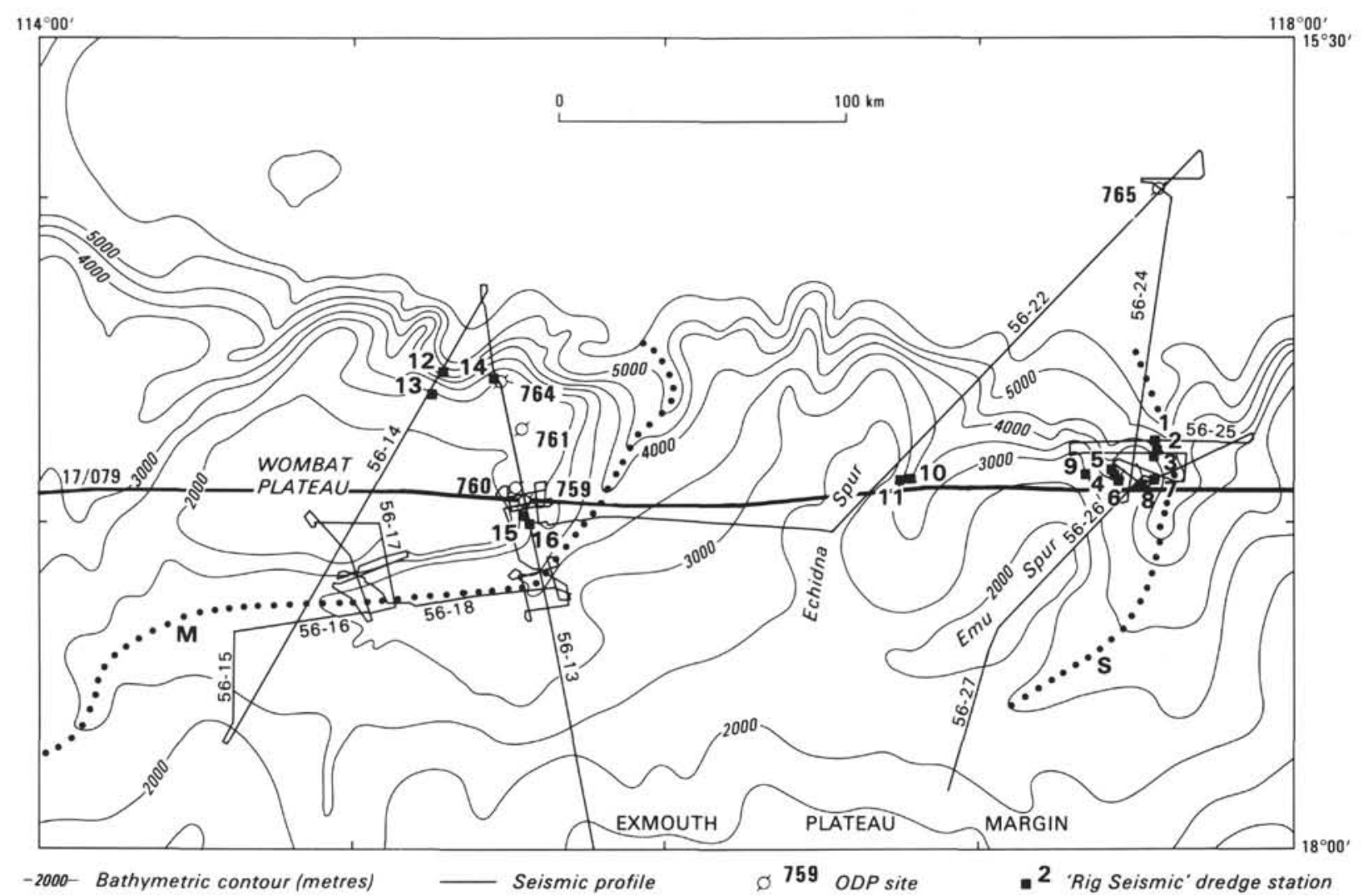

Figure 1. Bathymetric map of the northern Exmouth Plateau with the location of Rig Seismic sample sites and Leg 122 and Leg 123 drill sites. $\mathrm{M}=$ Montebello Canyon; $\mathrm{S}=$ Swan Canyon. (From von Rad et al., 1990.)

\section{PALEONTOLOGICAL RESULTS}

\section{Samples from Sonne Cruise 8}

Whitish Crinoidal Marl (Sample S08-61KD, Northern Slope of the Wombat Plateau)

\section{Foraminifers}

A washed sample from the whitish crinoidal marl contained the following foraminifers known from the Upper Triassic and unknown in the Lower Jurassic (Liassic):

Frondicularia rhaetica Kristan-Tollmann, S08-61KD/lithology 3.2 (Pl. 2, Fig. 1)

Berthelinella rhaetica Kristan-Tollmann, S08-61KD/lithology 3.1 (Pl. 2, Fig. 2)

\section{Echinoderms}

Holothurians:

Fissobractites subsymmetrica Kristan-Tollmann, S08$61 \mathrm{KD} / 3$ (Pl. 2, Figs. 3, 4)

Eocaudina hexagona Kristan-Tollman, S08-61KD/3 (Pl. 2, Fig. 5)

Ophiurians:

Ophioflabellum cristatum Kristan-Tollmann, S08-61KD/lithology 3.2 (Pl. 2, Figs. 7-10)

Ophioderma? cf. waliabadensis Kristan-Tollmann, S08$61 \mathrm{KD} /$ lithology 3.1 (Pl. 2, Fig. 11)

Ophiacantha ? binitorulosa Kristan-Tollmann, S08-61KD/ lithology 3.2 (Pl. 3, Figs. 7, 8)
Ophiacantha ? subtilirugosa Kristan-Tollman n. sp., S08$61 \mathrm{KD} /$ lithology 3.2 (Pl. 3, Figs. 1-6)

\section{Ostracodes}

Monoceratina (Neom.) cf. seebergensis (Pl. 4, Fig. 3) Mostlerella n. sp. (Pl. 4, Fig. 4)

Hasibuana asiatica Kristan-Tollmann (Pl. 4, Figs. 5-7)

Cytherelloidea cf. unicostata Bolz (Pl. 4, Figs. 1, 2)

Ogmoconchella cf. martini (Anderson) (Pl. 4, Fig. 8)

Ogmoconchella cf. aspinata (Drexler) (Pl. 4, Figs. 9-12)

White Sparry Biocalcarenite (Sample S08-62KD, Northern Slope of the Wombat Plateau)

\section{Ostracodes}

Ptychobairdia hettangica (Donze) (Pl. 4, Figs. 13, 14)

Ogmoconchella cf. aspinata (Drexler) (Pl. 4, Figs. 9-12)

Thin Sections of Sample S08-61KD/3 (Northern Slope of the Wombat Plateau)

\section{Foraminifers}

Involutina liassica (Jones) (PI. 1, Fig. 1)

Involutina turgida Kristan (Pl. 1, Fig. 2)

Trocholina turris Frentzen (Pl. 1, Fig. 3)

Coronipora austriaca (Kristan) (PI. 1, Fig. 9)

Variostoma sp.

\section{Age Assignment}

The microfauna from the washed samples dredged at station S08-61KD as figured by Quilty (1981) contains foraminifers, 


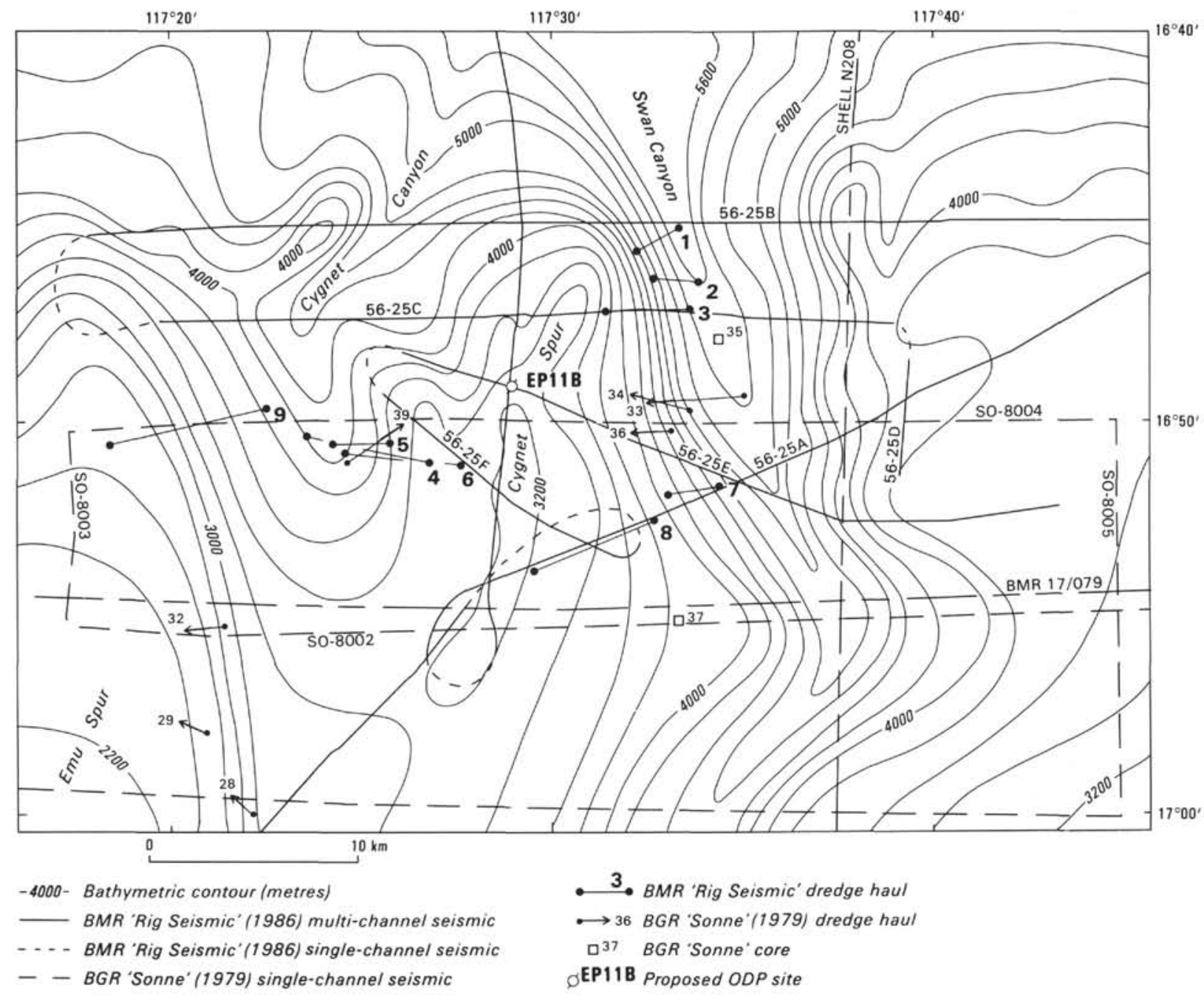

Figure 2. Bathymetric map of the Swan Canyon-Emu Spur area with the location of Rig Seismic and Sonne seismic lines and dredge hauls. (From von Rad et al., 1990.)

which were originally described from the German Liassic and are commonly regarded as characteristic species of Lower Jurassic shales. They have, however, also been observed in Tethyan marls of Rhaetian age, as well as in the Zlambachmergel facies described by Kristan-Tollmann (1964) and in the intraplatform marl of the Kössener Schichten (E. Kristan-Tollmann, unpubl. data). The other foraminifers, which are represented by single juvenile tests, are Frondicularia rhaetica and Berthelinella rhaetica. They are as yet unknown in Lower Jurassic sediments and indicate a Rhaetian age.

The ostracodes from sample S08-61KD are either recorded from the Lower Jurassic, as, for instance, Monoceratina (Neomonoceratina) seebergensis, or confined to the Triassic, such as Mostlerella n. sp. and Hasibuana asiatica. The Ogmoconchella species differ slightly from their Northwest European Rhaetian and Early Jurassic types, which have also been observed in the Rhaetian Kössener Schichten but not in the coeval Zlambachmergel. The small number of poorly preserved individuals makes it difficult to decide whether two species of Ogmoconchella are present or only one.

Based on our present knowledge, all the determined echinoderms are restricted to the Triassic.
The foraminifers from thin-section $\mathrm{S} 08-61 \mathrm{KD} / 3$ are indicative of a Rhaetian age. The species Involutina liassica, I. turgida, and Trocholina turris are known from the Rhaetian, as well as from the Liassic; they are distributed throughout the Tethys. The same geographic distribution also has Coronipora austriaca, which is, however, confined to the Rhaetian. The four species have been observed together in the Kuta Limestone of the highlands of Papua New Guinea (Kristan-Tollmann, 1986, textfig. 1, figs. 4, 7, 8, and text-fig. 2, figs. 1-3). They are present there with Variostoma cochlea, an index fossil of the Rhaetian. Our material contains only an oblique section of Variostoma without the possibility of specific identification.

In summarizing the observed faunal indicators, it has to be considered that among the foraminifers, which were originally described only from the Lower Jurassic, many are now also recorded from Upper Triassic sediments throughout the world, from Alaska (Tappan, 1951), the British Islands (Copestake, 1989) and the Tethys realm, including the Alps and New Zealand (Strong, 1984). Some genera and species have been traced back to the Middle Triassic (Anisian) on the Northwest Shelf of Australia (Heath and Apthorpe, 1986). Sample S08-61KD contains genera and 


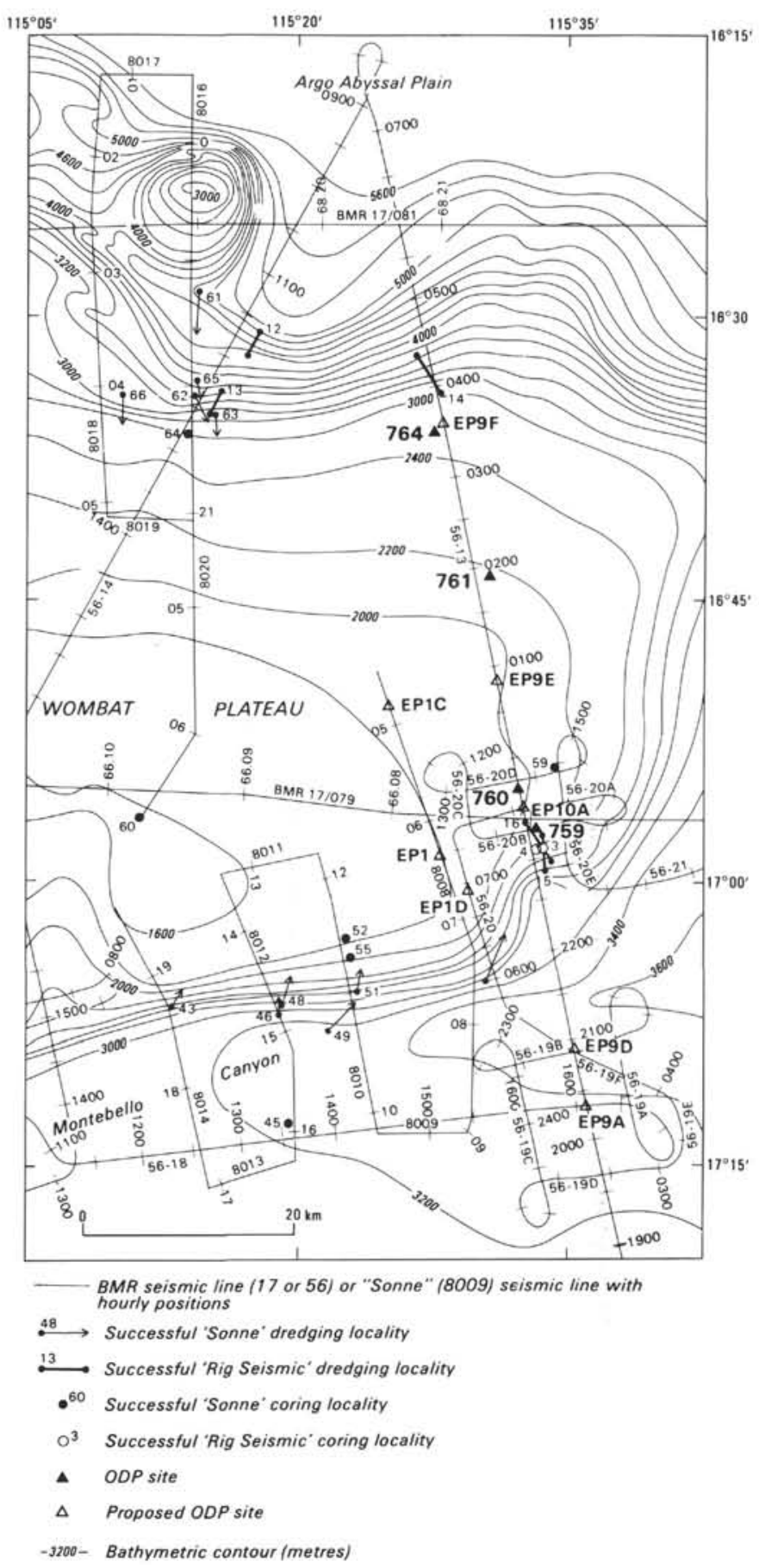

Figure 3. Bathymetric map of the northeastern Wombat Plateau area with the location of Rig Seismic and Sonne seismic lines and dredging and coring sites. (Courtesy of U. von Rad.)

species that were not previously recorded from the Lower Jurassic. Because this group is well represented, the dredge samples should be regarded as sediments of Norian to Rhaetian age. Dépêche and Crasquin-Soleau (this volume) described ostracodes from Sites 761 and 764, drilled close to the dredge haul positions, and identified their biostratigraphic ranges as partly conspecific and indicating the same time interval. This suggests that the Rhaetian formation cored at Sites 761 and 764 crops out at the steep escarpment of Wombat Plateau (see Fig. 4).

\section{Samples from Rig Seismic Cruise 56}

\section{Northern Slope of the Wombat Plateau}

\section{Foraminifers}

Four thin-sections contain the following foraminifers.

Trocholina crassa Kristan, RS56-DR13L (PI. 1, Fig. 6) Trocholina crassa Kristan, RS56-DR13L1 (Pl. 1, Fig. 7)

Variostoma sp., RS56-DR13L1

Trocholina laevis Kristan, RS56-DR13L2 (PI. 1, Figs. 8, 10) Ophtalmidium ? sp., RS56-DR13L2 (Pl. 1, Fig. 4)

Variostoma sp., RS56-DR13L2

Variostoma coniforme Kristan-Tollmann, RS56-DR14A (P1. 1, Fig. 13)

The foraminifers, taken together with the lithofacies of the sections, are indicative of the Dachsteinkalk facies equivalent to the Rhaetian. Their Tethys-wide distribution is well documented. The different species extend also into the earlier Late Triassic, but are never younger than Rhaetian. Though the species were first described from the Alps, they have since been recorded as far east as Papua New Guinea (Kristan-Tollmann, 1986, p. $204 \mathrm{ff}$., fig. 2). The distribution of Variostoma coniforme in North America was documented by Kristan-Tollmann and Tollmann (1983, p. 229) and Kristan-Tollmann (1988a, p. 248) from limestones of Norian age in Nevada and Oregon. As previously mentioned, Wonders (in Haq, von Rad, O'Connell, et al., 1990, pp. 368-369) suggested that samples from Rig Seismic cruise 56, considered to be Early Jurassic based on a determination for Trocholina umbo by M. Schott (unpubl. data) might be older, because the Trocholina might be Trocholina crassa or Trocholina permodiscoides?. The presence of Trocholina crassa has been confirmed here (Pl. 1, Figs. 6 and 7, with the pearshaped lumina also shown in section). Trocholina laevis, which has a similar thick shell, is smaller and flatter than $T$. crassa, and its lumina are always circular in cross section (Pl. 1, Figs. 8 and $10)$.

Trocholina umbo is considered a junior synonym of Trocholina granosa Frentzen in the sense of Wicher (1951). First described from the lower Liassic of southwestern Germany, the species has since been recorded in the Rhaetian throughout the Tethys, but is also known to occur commonly in Lower Jurassic limestones of the Alpine region.

\section{Cygnet Canyon Subarea}

\section{Foraminifers}

The two examined thin sections are rich in foraminifers, which, however, are heavily recrystallized and therefore largely undeterminable. Some are better preserved and show fossil outlines:

Glomospirella friedli Kristan-Tollmann, S08-39KD/11 (Pl. 1, Figs. 11, 14, 15)

Glomospirella friedli Kristan-Tollmann, RS56-DR04I (Pl. 1, Fig. 12)

Glomospirella friedli Kristan-Tollman (1962) was identified by A. Wonders (in Haq, von Rad, O'Connell, et al., 1990, p. 368) in Sample 122-764A-7R-1, 24-27 cm. In the Eastern Alps the species is present mainly in the Norian Hauptdolomit and in the Norian to Rhaetian bedded, lagoonal Dachsteinkalk.

\section{Emu Escarpment Subarea}

Most of these thin sections are free of determinable fossils. Only thin-section sample S08-32KD/2c shows longitudinal and 


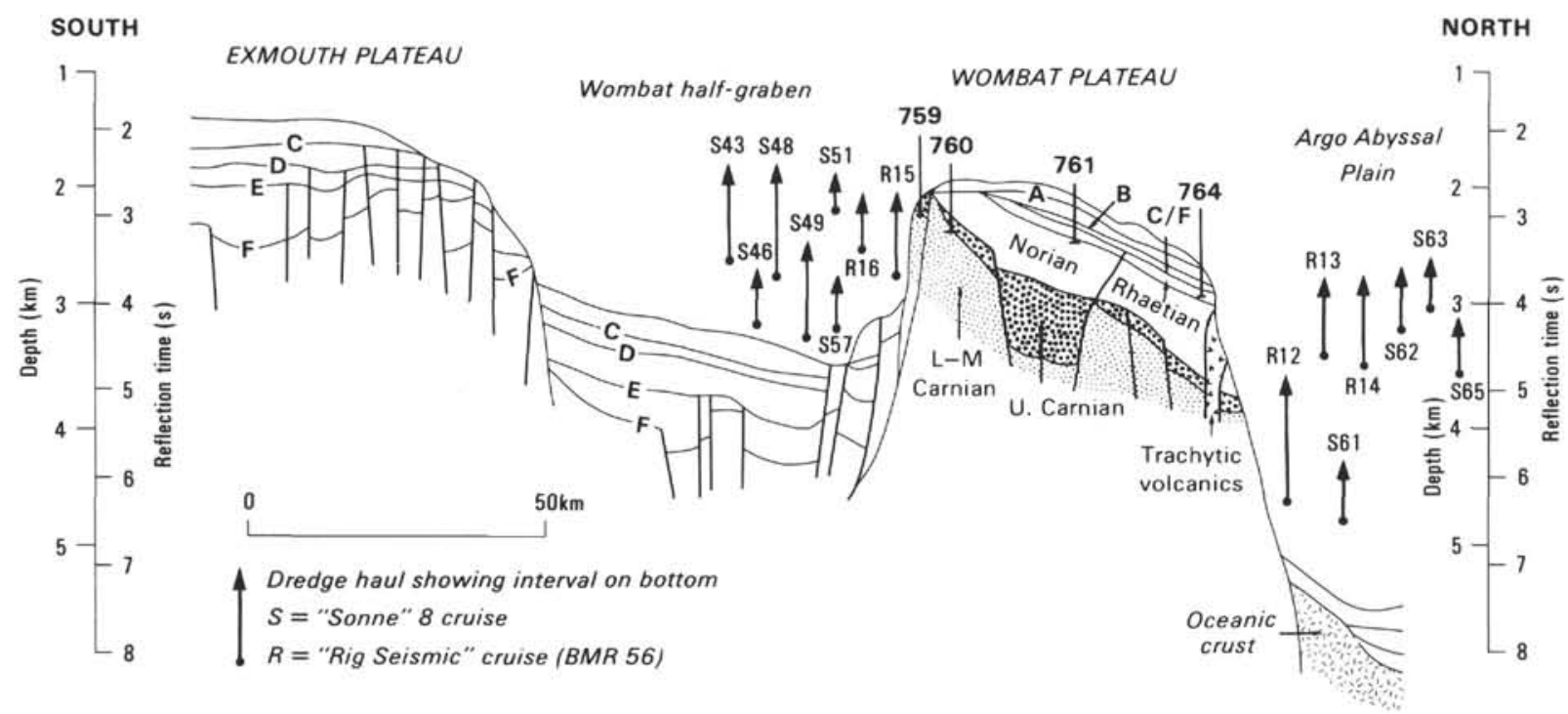

Figure 4. Line drawing of Rig Seismic multichannel seismic profile BMR 56-13 (Fig. 1). Interpretation of the seismic reflectors of the Wombat Plateau is after Haq, von Rad, O'Connell, et al. (1990). The length of the arrows indicates the depth range of the dredge hauls projected on the northern escarpment of the Wombat Plateau. (Modified after von Rad et al., this volume.)

Table 1. Location of dredge samples collected during Sonne cruise 8 and Rig Seismic cruise 56 along the northern Exmouth Plateau.

\begin{tabular}{|c|c|c|c|c|}
\hline Dredge no. & Latitude & Longitude & $\begin{array}{l}\text { Water depth } \\
\text { (m) }\end{array}$ & Major lithology \\
\hline $\mathrm{S} 08-32 \mathrm{KD} / 2 \mathrm{c}$ & $16^{\circ} 55.2^{\prime}-16^{\circ} 55.2^{\prime}$ & $117^{\circ} 21.3^{\prime}-117^{\circ} 20.3^{\prime}$ & $2950-2470$ & Foraminiferal biomicrite \\
\hline S08-39KD/11 & $16^{\circ} 51.0^{\prime}-16^{\circ} 49.7^{\prime}$ & $117^{\circ} 24.6^{\prime}-117^{\circ} 26.7^{\prime}$ & $4010-3850$ & Quartzose pelsparite \\
\hline $\begin{array}{l}\mathrm{S} 08-61 \mathrm{KD} / 2, \\
\mathrm{~S} 08-61 \mathrm{KD} / 3 \\
\mathrm{~S} 08-61 \mathrm{KD} / 3.2\end{array}$ & $16^{\circ} 28.7^{\prime}-16^{\circ} 30.7^{\prime}$ & $115^{\circ} 14.4^{\prime}-115^{\circ} 14.3^{\prime}$ & $4800-4260$ & $\begin{array}{l}\text { Foraminifer-pelecypod- } \\
\text { echinoderm biocalc- } \\
\text { arenite to -rudite }\end{array}$ \\
\hline S08-62KD & $16^{\circ} 34.2^{\prime}-16^{\circ} 35.2^{\prime}$ & $115^{\circ} 14.2^{\prime}-115^{\circ} 15.0^{\prime}$ & $3110-2580$ & White sparry biocalcarenite \\
\hline RS56-DR04I & $16^{\circ} 50.4^{\prime}-16^{\circ} 51.0^{\prime}$ & $117^{\circ} 23.4^{\prime}-117^{\circ} 26.5^{\prime}$ & $3970-3360$ & Biocalcarenite \\
\hline $\begin{array}{l}\text { RS56-DR13L, } \\
\text { RS56-DR13L1, } \\
\text { RS56-DR13L2 }\end{array}$ & $16^{\circ} 34.0^{\prime}-16^{\circ} 35.1^{\prime}$ & $115^{\circ} 15.6^{\prime}-115^{\circ} 15.0^{\prime}$ & $3380-2800$ & $\begin{array}{l}\text { Foraminifer-mollusk- } \\
\text { echinoderm biocalcarenite }\end{array}$ \\
\hline RS56-DR14A & $16^{\circ} 31.3^{\prime}-16^{\circ} 34.0^{\prime}$ & $115^{\circ} 26.5^{\prime}-115^{\circ} 27.8^{\prime}$ & $3440-2690$ & $\begin{array}{l}\text { Recrystallized sparry } \\
\text { limestone }\end{array}$ \\
\hline
\end{tabular}

transverse sections of an Anomuran coprolite. It is of some interest, as many such sections have been obtained from a limestone of late Anisian age in the Yuat River area of Papua New Guinea.

Blau et al. (1987) had erected a new genus of Anomuran coprolites as Octotriangulella after the eight triangular sectors of their type species from the German Liassic (Lower Jurassic). Though the species from the Emu Escarpment, as well as the material from Papua New Guinea, has only seven triangular sectors, it can only be classified only as a new species, not a new genus:

Octotriangulella septemtriangula Kristan-Tollmann (PI. 1, Fig. 5)

\section{TAXONOMIC NOTES}

\section{Foraminifers}

Frondicularia rhaetica Kristan-Tollmann, 1964

$$
\text { (Pl. 2, Fig. 1) }
$$

Frondicularia rhaetica n. sp. Kristan-Tollmann, 1964, p. 146, pl. 32, figs. $1-8$.
Frondicularia rhaetica Kristan-Tollmann in Tollmann and KristanTollmann (1970), pl. 8, fig. 15.

Frondicularia otamitaensis n. sp. Strong, 1984, p. 21, pl. 2, figs. 40-41.

Frondicularia rhaetica Kristan-Tollmann in Strong, 1984, p. 21, pl. 2, figs. 42-46; pl. 8, figs. 172, 174.

Frondicularia rhaetica Kristan-Tollmann, 1964 in Kristan-Tollmann and Gupta, 1987, p. 478, text-fig. 2/10.

Remarks. Frondicularia rhaetica is present in all the marl units of Rhaetian age in the Eastern Alps and is known throughout the Tethys to the southeastern border region of New Zealand, where its occurrence is already in the Norian.

\section{Berthelinella rhaetica Kristan-Tollmann, 1970}

(Fig. 5 and Pl. 2, Fig. 2)

Berthelinella rhaetica $\mathrm{n}$. sp. Kristan-Tollmann in Tollmann and Kristan-Tollmann, 1970, p. 126, text-fig. 20; pl. 8, fig. 25.

Remarks. Berthelinella sp. is common in the Zlambachmergel of the Plackles type, which is closely connected to reefal facies, but rather rare in more distal, open basin locations. From eastern Tethys localities, the species was previously unknown. Berthelinella perplexa Quilty (1981) and Berthelinella apthorpae Quilty (in press), however, may be conspecific. 

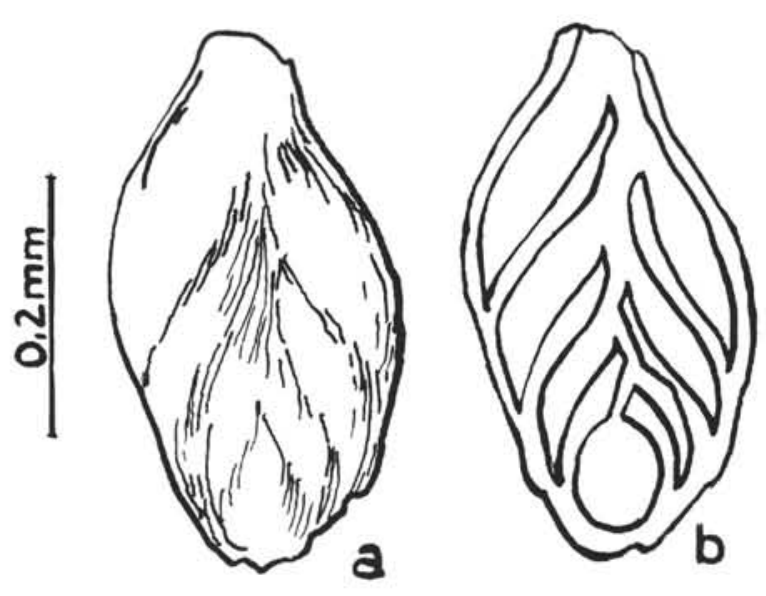

Figure 5. Berthelinella rhaetica Kristan-Tollmann, 1970. A. Surface. B. Transmitted light. Juvenile A-generation from washed sample S08-61KD/lithology 3.1, Wombat Plateau (northern Exmouth Plateau). Late Triassic (Rhaetian). The other side of the same individual is shown on Plate 2.

\section{Holothurian Sclerites}

Fissobractites subsymmetrica Kristan-Tollmann, 1963 (Pl. 2, Figs. 3, 4)

Fissobractites subsymmetrica n. gen. n. sp. Kristan-Tollmann, 1963, p. 375 , pl. 9 , figs. $2-5$.

Fissobractites subsymmetrica Kristan-Tollmann, 1963 in KristanTollmann, 1988c, p. 218, fig. 4.

Remarks. As shown in the review by Kristan-Tollmann (1988c, p. 218 ), the species is most common in the Rhaetian, but has also been recorded from deposits of early Carnian or even earlier age. Until now, it was identified from localities in the Tethys between the Eastern Alps and Burma.

\section{Eocaudina hexagona Kristan-Tollmann, 1963}

(PI. 2, Fig. 5)

Eocaudina hexagona n. sp. Kristan-Tollmann, 1963, p. 374, pl. 9, fig. 7.

Remarks. Up to now, only a single fragment was known from the Zlambachmergel (Rhaetian) of the Fischerwiese locality near Aussee (Austria). Typical for the species is an arrangement of the generally hexagonal holes in alternating rows. As seen in the fragment from the Wombat Plateau, the holes may tend to become larger toward the edge of the element. The species is observed together with the more common Fissobractites subsymmetrica at the Austrian locality, as well as in the Wombat Plateau sample.

\section{Ophiurians}

Ophioflabellum cristatum Kristan-Tollmann, 1979 (Pl. 2, Figs. 7-10)

Ophioflabellum cristatum Kristan-Tollmann n. sp. in Kristan-Tollmann et al., 1979, p. 167, text-fig. 16, figs. 1-6.

Remarks. This characteristic species was originally described from the Heterastridian marls of Sevatian (late Norian) age at the salt well of Dizlu, $10 \mathrm{~km}$ northeast of Bagerabad, northeast of Isfahan (Iran). It is also present in the Kössen marls (Rhaetian) of the Steinplatte (Austria). Its identification in sample S08-61KD/lithology 3.2 extends the geographical distribution to include it among the taxa of Tethyswide distribution.

Ophioderma ? cf. waliabadensis Kristan-Tollmann, 1979 (Pl. 2, Fig. 11)

Remarks. Some of the lateralia present may belong to Ophioderma? waliabadensis, but are too poorly preserved for unambiguous deter- mination. First described from Rhaetian marls at two localities in Central Iran, they have also been observed from the Kössener Mergel of the Eastern Alps (E. Kristan-Tollmann, unpubl. data).

\section{Ophiacantha ? binitorulosa Kristan-Tollmann, 1979} (PI. 3, Figs. 7, 8)

Ophiacantha ? binitorulosa Kristan-Tollmann n. sp. in KristanTollmann et al., 1979, p. 163; text-fig. 14, figs. 1-3.

Remarks. Species identification was from few, poorly preserved elements. It was first described from the two Iranian localities mentioned previously.

\section{Ophiacantha ? subtilirugosa Kristan-Tollmann n. sp.

$$
\text { (Pl. 3, Figs. 1-6) }
$$

Derivation of name. From the Latin subtilis (subtle) and rugosus (plicated), after the finely plicated outer surface of the laterals.

Description. The eight laterals are moderately arched with faint or missing constriction. There are three to four medium-sized, not very projected bases of thorns and one or two flat pillars at the proximal edge. The whole surface consists of faint, subtle, slightly undulating transversal striae, some of which are branching or vanishing. The striae slightly coarsen toward the distal rim.

Remarks. The best fit, in consideration of the striation of the laterals, is Ophiura longivertebralis Wolburg, 1939, described from the Liassic of Lower Saxony. The laterals, however, differ by the tongue at the distal end of the base of the thorn, which is cufflike in lateral view (Wolburg, 1939, p. 27). Besides this, the bases of the thorns are smaller and more numerous (five to six).

Ophiacantha ? suprajurassica Hess, 1965, from the lower Oxfordian of Chapois (Departement Jura, Switzerland), has also a fine striated surface, mainly on the laterals of the middle part of the arm. The striation is, however, restricted to the distal parts of the laterals and is fainter than in our species. Moreover, the bases of the thorns are stronger and more numerous (usually four to six). This observation is confirmed in viewing the material of Hess (1966, p. 1031, figs. 9,10 , and 70-73). The thick annular bases of the thorns are very strong and projected on the constricted surface.

Ophiacantha ? biformis Hess, 1975, from the upper Oxfordian of Brocheten in the Gulden valley (Kanton Solothurn, Switzerland), has striations on only a few of its laterals. The striation, when present, is confined to the distal part. The species also shows five to six, heavy wartlike projections.

Type strata. Upper Triassic, Rhaetian marls.

Size. Holotype: length, $0.4 \mathrm{~mm}$; width, $0.35 \mathrm{~mm}$.

Holotype. Lateral view (PI. 3, Fig. 4).

Type locality. Northern slope of the Wombat Plateau, dredge sample S08-61KD (16 $30^{\prime} \mathrm{S}, 115^{\circ}, 14.4^{\prime} \mathrm{E} ; 4800-4260 \mathrm{~m}$ water depth).

\section{Ostracodes \\ Mostlerella n. sp. \\ (Pl. 4, Fig. 4)}

Remarks. The genus Mostlerella Kozur, 1971 (see Bunza and Kozur, 1971) is a typical representative of Triassic assemblages. It was hitherto recorded from the upper Anisian to the Rhaetian from Austria, Italy, Hungary, Iran, and Southern China, but also outside the Tethys realm, in the Carnian of the Sephardic facies from Spain. The single left valve belongs to a new species, differing from the known ones by the absence of an anteriomedian inflation or node.

\section{Hasibuana asiatica Kristan-Tollmann, 1990}

$$
\text { (PI. 4, Figs. 5-7) }
$$

Hasibuana asiatica Kristan-Tollmann n. gen. n. sp. in KristanTollmann and Hasibuan, 1990, pl. 1, figs. 1-5.

Remarks. The recently erected genus Hasibuana resembles the Triassic genera Rekocythere and Movschovitschia, but is a separate genus. So far, it is unknown in the western part of the Tethys realm. The species Hasibuana asiatica has been described from the Upper Triassic limestones of Misol Island in the Ceram Sea of Indonesia. 
Cytherelloidea $\mathrm{cf}$. unicostata Bolz, 1970

(Pl. 4, Figs. 1, 2)

Remarks. The single right and left valves available are differentiated from Cytherella jugosa (Jones, 1884) and from Cytherella unicostata Bolz, 1970 by a generally horizontal median ridge and a parallel part at the dorsum of the circular ridge. Some larval individuals of C. unicostata are, however, very close to our valves. As the variation of the Exmouth Plateau representative is still unknown, a decision on the taxonomic status within the species group must be kept open for lack of material.

Ogmoconchella martini (Anderson, 1964)

$$
\text { (PI. 4, Fig. 8) }
$$

Remarks. The difference between our left valve and the original description is the absence of the short, rounded caudal process. As described and figured by Bate $(1978,182$, pl. 2, fig. 10), the caudal process may be missing. The species, originally described as Hungarella? martini, is known from the middle Rhaetian Westbury Beds of Shropshire (United Kingdom) and the Rhaetian of Lower Saxony, where it has been described as "Ostrakode 800 " by Wicher (1951) and as Healdia ? tenuivirgata Will, 1969. H. ? martini is also well known from the Alpine Rhaetian throughout the Tethys realm. It is very common in the Kössen Beds at the type locality Weißlofer ravine near Kössen (Tyrol, Austria), common in the Kössen Beds at Steinplatte (Salzburg, Austria), and abundant in Rhaetian marls at Salt Spring near Bagerabad (near Isfahan, Central Iran).

Fingerprint sculpture in the posterior part of the carapace is seen in other Healdiidae, for instance, in Ogmoconchella adenticulata (Pietrzenuk, 1961), which was originally described from the upper Pliensbachian. The valves of this species are more elongate. Other representatives of the genus Ogmoconchella from our samples have smooth outer surfaces, but are similar in the remaining character. As the number of individuals is small and the preservation far from excellent, it is difficult to decide whether two species are present.

Ogmoconchella cf. aspinata (Drexler, 1958)

(Pl. 4, Figs. 9-12)

Remarks. The ostracodes, tentatively compared here with Ogmoconchella aspinata, which was originally described from the Hettangian of Germany, are smooth and ovoid, with a better rounded and inflated posterior part of the shell and a slight dorsal angle not far behind mid-length. The species was included as a synonym of Ogmoconcha ellipsoidea (Jones, 1872) by Lord (1971), who also discussed a possible synonomy with Hungarella owthorpensis Anderson, 1964, from the English Rhaetian.

The small assemblage of ostracodes from the washed samples from station S08-62KD consists of two valves of the readily determinable Ptychobairdia hettangica (Donze) and of some mostly larval Ogmoconchella valves and carapaces, poor in specific character and preservation.

Theoretically, a Liassic age should be considered first, as Ptychobairdia hettangica is as yet unknown from Rhaetian sediments. The stratigraphic value of the Ogmoconchella representatives is uncertain. But the possibility that the range of $P$. hettangica may be expanded can not be excluded, and the age of the sample remains in doubt.

\section{Ptychobairdia hettangica (Donze, 1966)}

(Pl. 4, Figs. 13, 14)

Bairdia ? hettangica n. sp. Donze, 1966, p. 129, pl. 6, figs. 57-66. Ptychobairdia? hettangica (Donze, 1966) in Oertli, 1985, p. 110, pl. 23, fig. 1.

Remarks. The low-arched dorsal rim and the shape of the circular ridge are characteristic for this species. It does not form a symmetric ovoid, but is ventrally broader and more elevated and therefore different from that of the Alpine species Ptychobairdia gracilis (Kristan-Tollmann, 1970) of the same age.

Distribution. $P$. hettangica was previously known from the early Hettangian Planorbis Zone of the Ardèche, France.

\section{PALEOGEOGRAPHIC CONCLUSIONS}

Although the samples from the northern Exmouth Plateau contain only small microfaunal assemblages, they neverthe- less represent three distinct characteristic biofacies and lithofacies types.

1. The whitish crinoidal marls of sample S08-61KD, from the northern slope of the Wombat Plateau, contain mainly echinoderms and ostracodes typical of the Alpine Kössen Beds (formed in an intraplatform basin), especially for the subtype Steinplatte (Salzburg, Austria), which reflects a marginal position on the outer rim of the platform, close to the reef margin with channels to the fore-reef basin. A proximity to reefs is indicated by the ophiurids. This is comparable to a typical association in the Rhaetian marls intercalated between coral patch reefs at Salt Spring near Isfahan, Iran (Kristan-Tollmann et al., 1979). The same correlation is indicated for the majority of the ostracodes. The foraminifers of the limestones from the same dredge sample also evidence a perireefal environment.

2. The limestones of sample RS56-DR13, from the northern slope of the Wombat Plateau, contain Trocholina sp. and Variostoma sp. and correlate with the Rhaetian Dachstein reef limestone facies.

3. The recrystallized carbonates from the Cygnet Canyon (S08-39KD/11 and RS56-DR04I) reflect a lagoonal facies, as indicated by the abundance of Glomospirella friedli KristanTollmann.

During Triassic times, the transition from the Tethyan to the Pacific facies realm occurred between New Caledonia and New Zealand. This transition is proved by an interfingering of Tethyan and Pacific macrofossils and microfossils (KristanTollmann, 1986, 1987). On the other hand, typical Dachsteintype limestones belonging to five distinct Alpine facies types with their typical Tethyan microfauna were also found in allochthonous terranes in Japan (Kristan-Tollmann, in press).

Detailed biostratigraphic study of the dredge samples from the Exmouth Plateau has shown the presence of species, genera, and characteristic lithofacies that were first described from the Alps (western Tethys). Together with observations from material from Timor, Papua New Guinea, and sites farther in the eastern Tethys (Kristan-Tollmann, 1988a, 1988b, $1988 \mathrm{c}$ ) this is a strong indication that the faunas can be well correlated across the whole paleobiogeographic realm of Tethys, from the Alps in the west via Exmouth Plateau to Papua New Guinea and Japan in the east.

\section{ACKNOWLEDGMENTS}

Dr. U. von Rad (BGR, Hannover) stimulated this study and supplied most of the dredge material, as well as Figures 1-4. Dr. U. Röhl (BGR, Hannover) supplied the information for Table 1. Dr. P. Quilty (Antarctic Division, Tasmania, Australia) kindly sent us washed residues of the material he studied in 1980 . The SEM micrographs of Plates 2 and 3 were graciously provided by the Geosciences Department of the University of Marburg (Lahn) through Prof. Dr. W. Tufar and K. Fecher. Plate 4 is mainly the result of the combined efforts of Mr. Luppold and Mr. Zika from the Hannover surveys NLfB and BGR. We are grateful to Drs. U. von Rad and U. Röhl for fruitful discussions and to Drs. U. von Rad, W. Resch (Innsbruck, Austria), and D. Haig (Nedlands, Western Australia) for reviewing this manuscript.

\section{REFERENCES}

Anderson, F. W., 1964. Rhaetic Ostracoda. Bull. Geol. Surv. G.B., 21:133-174.

Bate, R. H., 1978. The Trias. In Bate, R. H., and Robinson, E. (Eds.), A Stratigraphic Index of British Ostracoda. Geol. J. Spec. Iss., $8: 175-187$.

Blau, J., Lukas, V., and Stein, R., 1987. Octotriangulella bonenburgensis n.g.n.sp., ein Anomuren-Koprolith aus dem unteren Lias 
(Sinemur). Neues Jahrb. Geol. Palaeontol. Monatsh., 1987:641646.

Bolz, H., 1970. Einige Cytherelloidea-Arten (Ostrac.) aus der alpinen Ober trias. Senckenbergiana Lethaea, 51:239-263.

Bunza, G., and Kozur, H., 1971. Beiträge zur Ostracoden fauna der tethyalen Trias. Geol. Palaontol. Mitt. Innsbruck, 1:1-76.

Copestake, P., 1989. Triassic. In Jenkins, D., and Murray, J. W. (Eds.), Stratigraphical Atlas of Fossil Foraminifera (2d ed.): London (Ellis Horwood), 91-124.

Donze, P., 1966. Ostracodes de l'Hettangien entre Aubenas et Privas (Ardéche). Trav. Lab. Geol. Fac. Sci. Lyon, n.s., 13:121-139.

Drexler, E., 1958. Foraminiferen und Ostracoden aus dem Lias alpha von Siebeldingen/Pfalz. Geol. Jahrb., 75:475-554.

Exon, N. F., von Rad, U., and von Stackelberg, U., 1982. The geological development of the passive margins of the Exmouth Plateau off northwest Australia. Mar. Geol., 47:131-152.

Exon, N. F., and Williamson, P. E., 1988. Preliminary post-cruise report, Rig Seismic research cruises 7 \& 8: sedimentary basin framework of the northern and western Exmouth Plateau. Bur. Min. Resour. Aust. Rec., 1988/30.

Haig, D., 1979. Early Jurassic foraminiferids from the Western Highlands of Papua New Guinea. Neues Jahrb. Geol. Palaeontol. Monatsh., 1979:208-215.

Haq, B. U., von Rad, U., O'Connell, S., et al., 1990. Proc. ODP, Init. Repts., 122: College Station, TX (Ocean Drilling Program).

Heath, R. S., and Apthorpe, M. C., 1986. Middle and Early (?) Triassic foraminifera from the Northwest Shelf, Western Australia. J. Foraminiferal Res., 16:313-333.

Hess, H., 1965. Mikropaläontologische Untersuchungen an Ophiuren. IV. Die Ophiuren aus dem Renggeri-Ton (Unter-Oxford) von Chapois (Jura) und Longecombe (Ain). Eclogae Geol. Helv., 58:1059-1082.

1966. Mikropaläontologische Untersuchungen an Ophiuren. V. Die Ophiuren aus dem Argovien (unteres Ober-Oxford) vom Guldental (Kt. Solothurn) und von Savigna (Dépt. Jura). Ibidem, 59:1025-1063.

1975. Mikropaläontologische Untersuchungen an Ophiuren. VI. Die Ophiuren aus den Günsberg-Schichten (oberes Oxford) vom Guldental (Kt. Solothurn). Ibidem, 68:591-601.

Jones, T. R., 1884. Notes on the Foraminifera and Ostracoda from the Deep Boring at Richmond. Quart. J. Geol. Soc., 40:765777.

Kristan, E., 1957. Ophthalmidiidae und Tetrataxinae (Foraminifera) aus dem Rhät der Hohen Wand in Nieder-Osterreich. Jahrb. Geol. Bundesanst. Austria, 100:269-298.

Kristan-Tollmann, E., 1960. Rotaliidea (Foraminifera) aus der Trias der Ostalpen. Jahrb. Geol. Bundesanst. Austria, 5:47-78. 1962. Stratigraphisch wertvolle Foraminiferen aus Obertrias- und Liaskalken der voralpinen Fazies bei Wien. Erdoel Z., $78: 228-233$

1963. Holothurien-Sklerite aus der Trias der Ostalpen. Sitzungber.-Oesterr. Akad. Wiss., Math.-Naturwiss. Kl., Abt. l, 172:351-380.

1964. Die Foraminiferen aus den rhätischen Zlambachmergeln der Fischerwiese bei Aussee im Salzkammergut. Jahrb. Geol. Bundesanst. (Austria), 10:1-189.

1970. Einige neue Bairdien (Ostracoda) aus der alpinen

Trias. Neues Jahrb. Geol. Palaeontol. Abh., 135:268-310. 1986. Beobachtungen zur Trias am Südostende der TethysPapua/Neuguinea, Australien, Neuseeland. Neues Jahrb. Geol. Palaeontol. Monatsh., 1986:201-222.

1987. Triassic of the Tethys and its relations with the Triassic of the Pacific Realm. In McKenzie, K. G. (Ed.), Shallow Tethys 2: Rotterdam (A. A. Balkema), 169-186.

1988a. A comparison of Late Triassic agglutinated foraminifers of western and eastern Tethys. Abh. Geol. Bundesanst. (Austria), 41:245-253. 1988b. Unexpected communities among the crinoids within the Triassic Tethys and Panthalassa. In Burke, R. D., et al. (Eds.), Echinoderm Biology. Proc. Sixth Int. Echinoderm Conf. Rotterdam (A. A. Balkema), 133-142.

1988c. Unexpected microfaunal communities within the Triassic Tethys. In Audley-Charles, M. G., and Hallam, A. (Eds.), Gondwana and Tethys. Geol. Soc. Spec. Publ. London, 37:213-223. in press. Triassic Tethyan microfauna in Dachstein Limestone blocks in Japan. Shallow Tethys 3.

Kristan-Tollmann, E., and Gupta, V. J., 1987. Remarks to the microfauna of the Rhaetian Kioto-Marls from Kumaun, Himalaya. Neues Jahrb. Geol. Palaeontol. Monatsh., 1987:467-492.

Kristan-Tollmann, E., and Hasibuan, F., 1990. Ostracoden aus der Obertrias von Misol (Indonesien). Mitt. Oesterr. Geol. Ges., 82.

Kristan-Tollmann, E., and Tollmann, A., 1983. Tethys-Faunenelemente in der Trias der USA. Mitt. Oesterr. Geol. Ges., 76:213272.

Kristan-Tollmann, E., Tollmann, A., and Hamedani, A., 1979. Beiträge zur Kenntnis des Trias von Persien. Mitt. Oesterr. Geol. Ges., 70:119-186.

Lord, A., 1971. Revision of some lower Lias Ostracoda from Yorkshire. Paleontology, 14:642-665.

Oertli, H. J. (Ed.), 1985. Atlas des Ostracodes de France. Mem. Bull. Cent. Rech. Explor.-Prod. Elf-Aquitaine, 9.

Pietrzenuk, E., 1961. Zur Mikrofauna einiger Liasvorkommen in der Deutschen Demokratischen Republik. Freiberg. Forschungsh. C, 113.

Quilty, P. G., 1981. Early Jurassic Foraminifera from the Exmouth Plateau, Western Australia. J. Paleontol., 55:985-995.

in press. Triassic and Jurassic foraminiferal faunas, northern Exmouth Plateau, eastern Indian Ocean. J. Foraminiferal Res.

Strong, C. P., 1984. Triassic Foraminifera from Southland Syncline, New Zealand. N. Z. Geol. Surv. Paleontol. Bull., 52:1-37.

Tappan, H., 1951. Foraminifera from the Arctic Slope of Alaska. General introduction and part I, Triassic foraminifera. Geol. Surv. Prof. Pap. U.S., 236A:1-20.

Tollmann, A., and Kristan-Tollmann, E., 1970. Geologische und mikropaläontologische Untersuchungen im Westabschnitt der Hallstätter Zone in den Ostalpen. Geol. Palaeontol., 4:87-145.

von Rad, U., and Exon, N. F., 1983. Mesozoic-Cenozoic sedimentary and volcanic evolution of the starved passive continental margin off northwest Australia. In Watkins, J. S., and Drake, C. L. (Eds.), Studies in Continental Margin Geology: AAPG Mem., 34:253-281.

von Rad, U., Schott, M., Exon, N. F., Mutterlose, J., Quilty, P., and Thurow, J., 1990. Mesozoic sedimentary and volcanic rocks dredged from the northern Exmouth Plateau: petrography and microfacies. BMR J. Aust. Geol. Geophys., 11:449-476.

von Stackelberg, U., Exon, N. F., von Rad, U., Quilty, P., Shafik, S., Beiersdorf, H., Seibertz, E., and Veevers, J. J., 1980. Geology of the Exmouth and Wallaby plateaus off northwest Australia: sampling of seismic sequences. BMR J. Aust. Geol. Geophys., 5:113-140.

Wicher, C. A., 1951. Zur mikropaläontologischen Gliederung des nichtmarinen Rhät. Erdoel Kohle, 4:755-760.

Will, H. J., 1969. Untersuchungen zur stratigraphie und genese des Oberkeupers in Nordwestdeutschland. Geol. Jahrb. Beih., 54:1-240.

Wolburg, J., 1939. Skelettreste von Ophiuren aus dem deutschen Lias, ihre systematische Zugehörigkeit und Bedeutung als Mikrofossilien. Palaontol. Z., 21:20-42.

Date of initial receipt: 11 June 1990

Date of acceptance: 22 February 1991

Ms 122B-186 

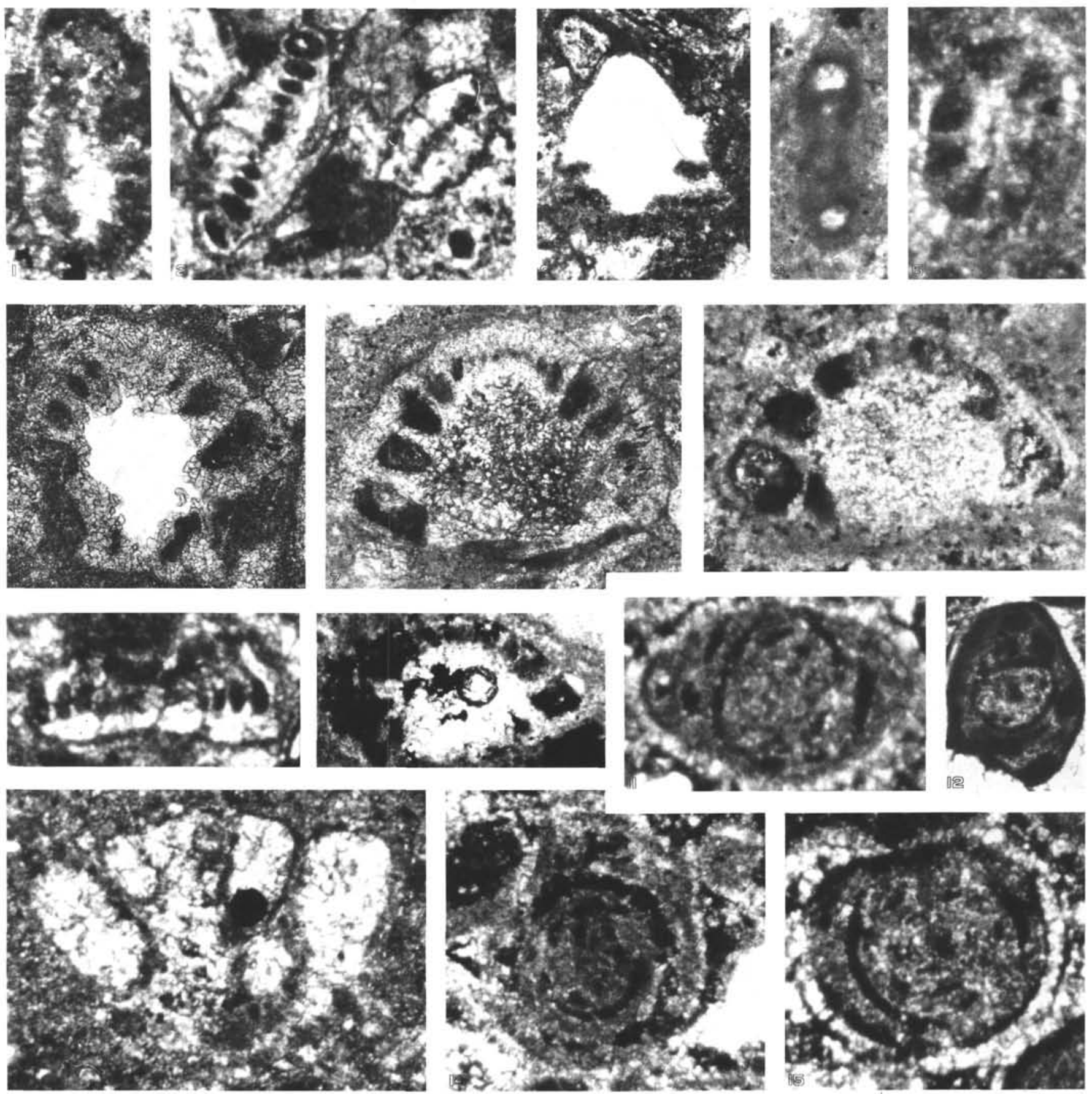

Plate 1. Foraminifers and Anomuran coprolite from thin sections of dredge samples from the northern Exmouth Plateau. 1. Involutina liassica (Jones, 1853), S08-61KD/3(1). 2. Involutina turgida (Kristan, 1957), S08-61KD/3. 3. Trocholina turris (Frentzen, 1941), S08-61KD/3(1). 4. Ophthalmidium ? sp., RS56-DR13L2. 5. Octotriangulella septemtriangula (Kristan-Tollmann, 1991), flattened, upright, from the Emu Escarpment, S08-32KD/2c. 6. Trocholina crassa (Kristan, 1957), RS56-DR13L. 7. Trocholina crassa (Kristan, 1957), RS56-DR13L1. 8. Trocholina laevis (Kristan, 1957), RS56-DR13L2. 9. Coronipora austriaca (Kristan, 1957), S08-61KD/3. 10. Trocholina laevis (Kristan, 1957), RS56-DR13L2. 11. Glomospirella friedli (Kristan-Tollmann, 1962), S08-39KD. 12. Glomospirella friedli (Kristan-Tollmann, 1962), RS56-DR04I. 13. Variostoma coniforme (Kristan-Tollmann, 1960), RS56-DR14A. 14, 15. Glomospirella friedli (Kristan-Tollmann, 1962), S08-39KD/11. 


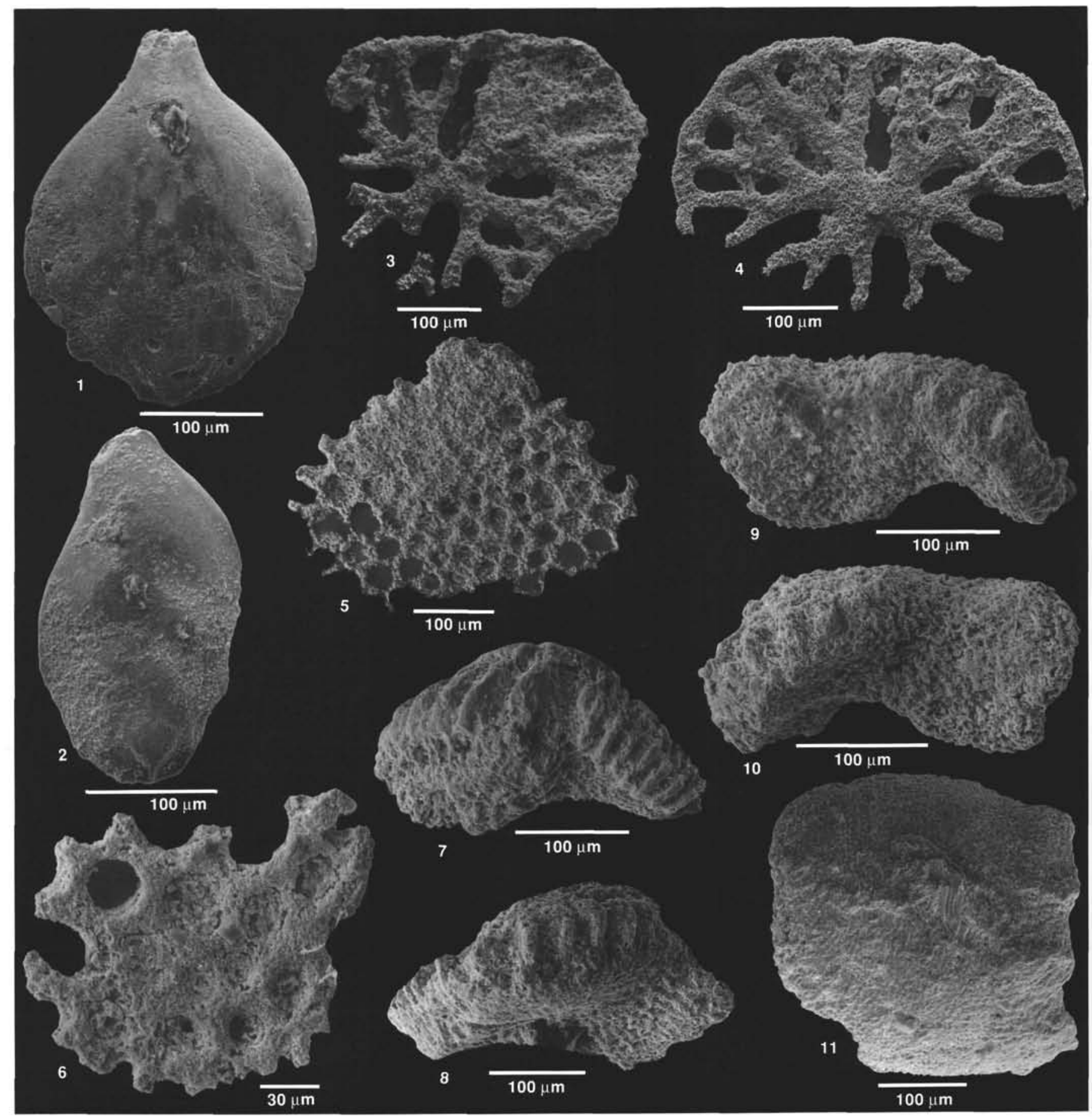

Plate 2. Foraminifers $(1,2)$, Holothurian sclerites (3-6), and laterals of Ophiura (7-11) from the uppermost Triassic (Rhaetian) of the northern slope of the Wombat Plateau. 1. Frondicularia rhaetica (Kristan-Tollmann, 1964), juvenile, S08-61KD/lithology 3.2. 2. Berthelinella rhaetica (Kristan-Tollmann, 1970), juvenile, S08-61KD/lithology 3.1. 3, 4. Fissobractites subsymmetrica (Kristan-Tollmann, 1963), fragments, S0861KD/3. 5. Eocaudina hexagon (Kristan-Tollmann, 1963), fragment, S08-61KD/3. 6. Eocaudina sp., fragment, S08-61KD/lithology 3.2. 7-10. Ophioflabellum cristatum (Kristan-Tollmann, 1979), S08-61KD/lithology 3.2. (7, 8) Fragments. (9, 10) Distal laterals from outer surface. 11. Ophioderma ? cf. waliabadensis (Kristan-Tollmann, 1979), lateral from the middle part of the arm, S08-61KD/lithology 3.1. 


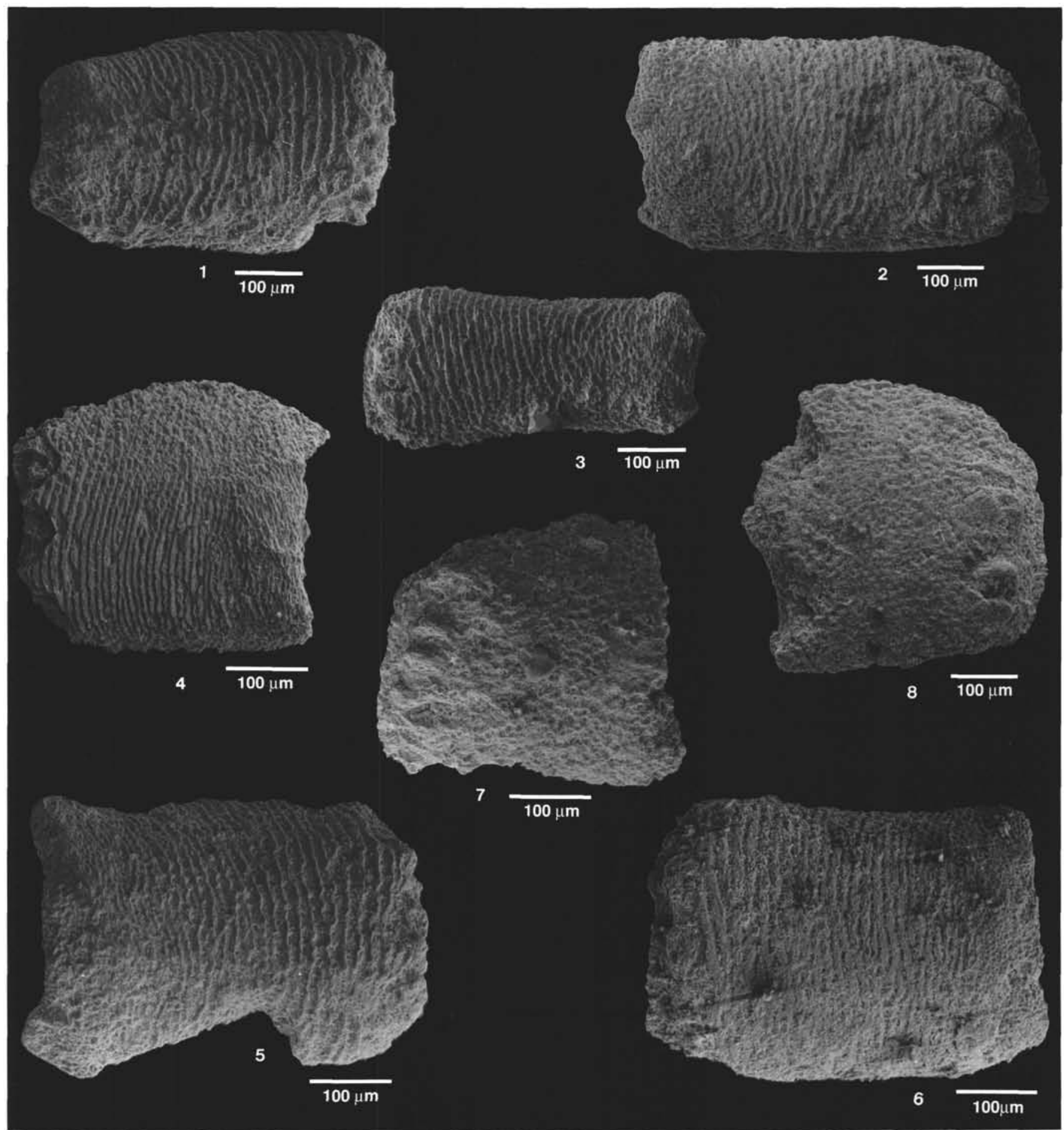

Plate 3. Lateralia of Ophiura from the uppermost Triassic (Rhaetian) of the northern slope of Wombat Plateau. 1-6. Ophiacantha ? subtilirugosa Kristan-Tollmann n. sp. $(1,2,5)$ S08-61KD/lithology 3.2. (3, 4, 6) S08-61KD/3. (4) Holotype. Lateral from the middle part of an arm, exterior. 7, 8. Ophiacantha ? binitorulosa (Kristan-Tollmann, 1979). Lateralia from the middle part of the arm, S08-61KD/lithology 3.2. (8) Fragment. 


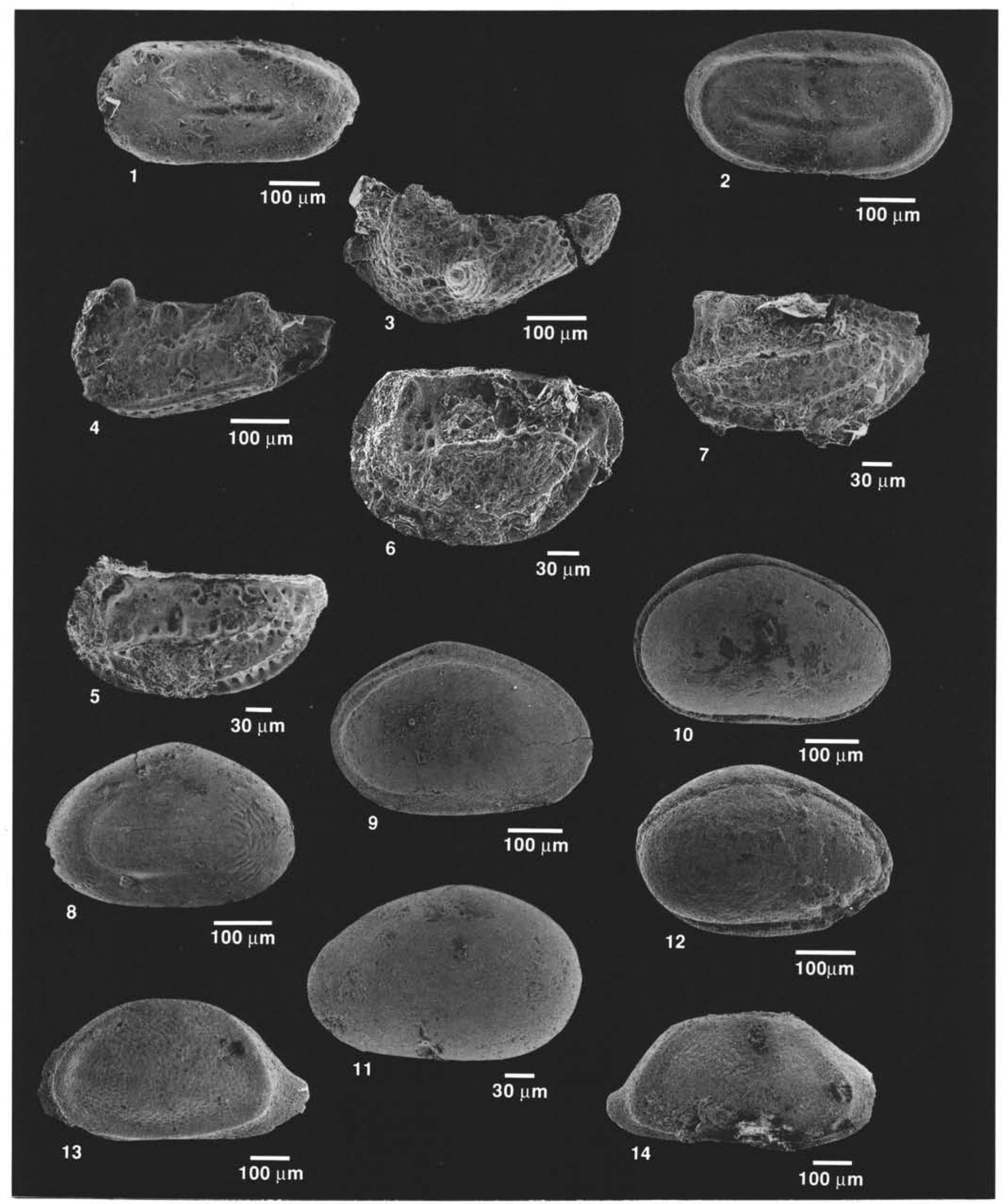

Plate 4. Ostracodes from rock samples from the northern slope of the Wombat Plateau. 1, 2. Cytherelloidea cf. unicostata (Bolz, 1970). (1) Left valve, S08-61KD/lithology 1. (2) Right valve, S08-61KD/lithology 1. 3. Monoceratina (Neom.) cf. seebergensis (Triebel and Bartstein, 1938), S08-61KD/2. 4. Mostlerella $\mathrm{n}$. sp., S08-61KD/2. 5-7. Hasibuana asiatica (Kristan-Tollmann, 1990), S08-61KD/2. 8. Ogmoconchella ? cf. martini (Anderson, 1964), left valve, S08-61KD/2. 9. Ogmoconchella cf. aspinata (Drexler, 1958), left valve, from interior, S08-62KD. 10. Ogmoconchella cf. aspinata (Drexler, 1958), carapace from right side, S08-62KD. 11. Ogmoconchella cf. aspinata (Drexler, 1958), left valve, S08-62KD. 12. Ogmoconchella cf. aspinata (Drexler, 1958), carapace from right side, S08-61KD/lithology 3.1. 13, 14. Ptychobairdia hettangica (Donze, 1966), S08-62KD. 